\title{
変形性能に優れた鉄筋コンクリート杭に支持される建物の地震応答解析 DYNAMIC ANALYSES OF BUILDING SUPPORTED BY REINFORCED CONCRETE PILES WITH GOOD DEFORMATION CAPACITY
}

\author{
長江拓也*, 内村 均**, 小林恒一***, 吉田 望****, 林 静雄***** \\ Takuya NAGAE, Hitoshi UCHIMURA, Kouichi KOBA YASHI, \\ Nozomu YOSHIDA and Shizuo HAYASHI
}

\begin{abstract}
This paper presents the results of dynamic analyses conducted with the aim of considering the damage of building supported by ductility piles. Soft first-story structure and frame structure were objects of analyses. Ductility piles were modeled as nonlinear beam with moment-curvature relation influenced by axial-force fluctuation. The pile-supported structure was connected with free ground by nonlinear Winkler springs. These analytical results indicated that the hysteretic damping of pile heads decreases the energy dissipation of upper structure, and thus the damage of upper structure can be controlled by ductility pile.
\end{abstract}

Keywords: Pile-supported structure, Ductility pile, Dynamic interaction, Yield of pile head,

Damages of building, Energy absorption

杭支持構造, 勒性杭, 動的相互作用, 杭頭降伏, 建物の損傷, エネルギー吸収

1.はじめに

以前より, 鉄筋コンクリート杭の変形性能向上に関する実験は精

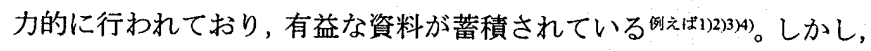
現状の設計では上部構造の保有耐力を保証するといった観点から， 基本的に杭の降伏を認めていない5)6)。

一方，建物に対する耐震設計は既に性能評価型に移行していく段 階に入っており, 今後は上部構造のみでなく, 基礎構造も含めた建 物全体としての構造性能を十分吟味することが必要となる。

例えば, 2 階以上が連層耐震壁で 1 階が独立柱のみになる構造形 式（以降，ピロティ構造）は大地震時における損傷制御が難しく, 1 階のエネルギー吸収のみに期待して 1 階層間変形角を制御するには 1 階層せん断力係数 $C b$ にして 0.45-1.0 という大きな保有水平耐力を 確保する必要がある》。このような場合において，杭頭のエネルギー 吸収に期待することが出来れば, 建物全体として合理的な設計につ ながる可能性がある。

近年においては，上部構造・杭基礎連成の地震応答解析に杭の塑 性化を考慮した研究 ${ }^{899110)}$ が行われるようになり，貴重な資料が蓄積 されてきている。ただし，これらの主眼は杭基整の応答に置かれて おり，杭の塑性化が上部構造の塑性性状に及ぼす影響は必ずしも明 らかになっていない。
そこで, 本研究においては; 部材レベルにおいて履歴特性を定義 した上部構造・杭基礎連成の地震応答解析により, そのエネルギー 吸収および塑性性状に関する考察を行う。

敷地は; 軟弱地盤である東京都の臨海副都心台場地区とする。上 部構造としては, 12 階建て鉄筋コンクリート造共同住宅（ピロティ 構造）と 12 階建て鉄筋コンクリート造事務所（ラーメン構造）の 2 ケースを設定し，それぞれ杭の主筋量を変化させることで上部と杭 基礎の構造バランスの違いを表現する。

\section{2. 解析概要}

\section{1 解析対象モデル}

対象とした建物は, 文献 7)を参考にした 12 階建て鉄筋コンク リート造共同住宅と、「終局強度型設計指針」5)の設計例 2 を参考に した 12 階建て鉄筋コンクリート造事務所である。

基礎梁, 敷地地盤, および杭は以下のように設定する。

(1) 基礎梁の成は軒高のおよそ $8 \%$ とする。

(2) 敷地地盤は「建築物の構造安全性に関する調查・検討」 ${ }^{11}$ に示さ れる台場地区とする。敷地地盤概要を表 -1に示す。

(3) 杭は場所打ちコンクリート拡底杭で, 支持層は東京碟層とする。 断面設定に関しては, 適当なせん断補強により中小地震時の損傷を JSPS Research Fellow, Tokyo Institute of Technology, Dr. Eng. (日本学術振興会)

*** 佐藤工業中央技術研究所工博

**** 佐藤工業中央技術研究所 工博

***** 東京工業大学建築物理研究センター 教授. 工博
Engineering Research Institute, Sato Kogyo Corp., Dr. Eng. Engineering Research Institute, Sato Kogyo Corp., Dr. Eng. Engineering Research Institute, Sato Kogyo Corp., Dr. Eng. Prof., Structural Engineering Research Center, Tokyo Institute of Technology, 
表-1 敷地地盤概要

\begin{tabular}{|c|c|c|c|c|c|c|c|}
\hline 地層分類 & $\begin{array}{c}\text { 深度 } \\
(\mathrm{m})\end{array}$ & $\begin{array}{c}L \\
(\mathrm{~m})\end{array}$ & $\begin{array}{c}V_{\mathrm{s}} \\
(\mathrm{m} / \mathrm{s})\end{array}$ & $\begin{array}{c}\rho \\
\left(\mathrm{tf} / \mathrm{m}^{3}\right)\end{array}$ & $N$ 值 & $\begin{array}{c}\gamma_{0.5} \\
\left(\times 10^{-3}\right)\end{array}$ & $\begin{array}{c}h \max \\
(\%)\end{array}$ \\
\hline 盛土 & -3.0 & 3.0 & 110 & 1.80 & 3 & 1.6 & 24 \\
\hline 埋土 & -5.5 & 2.5 & 110 & 1.52 & 3 & 1.0 & 22 \\
\hline \multirow{2}{*}{ 有楽町層 粘土 } & -7.5 & 2.0 & 80 & 1.52 & 1 & 1.4 & 23 \\
\cline { 2 - 8 } & -14.5 & 7.0 & 130 & 1.50 & 2 & 1.4 & 23 \\
\hline \multirow{2}{*}{ 東京層 砂 } & -17.5 & 3.0 & 170 & 1.70 & 10 & 0.9 & 27 \\
\cline { 2 - 8 } & -20.5 & 3.0 & 260 & 1.70 & 34 & 0.9 & 27 \\
\hline 東京層粘士 & -28.1 & 7.6 & 190 & 1.52 & 7 & 1.5 & 25 \\
\hline 東京礫層 & -32.5 & 4.4 & 370 & 2.05 & $>50$ & 0.9 & 25 \\
\hline 江戸川層 & -46.5 & 14.0 & 370 & 1.84 & $>50$ & - & - \\
\hline
\end{tabular}

$L$ : 層厚, $V_{\mathrm{s}}$ : せん断波速度, $\rho$ : 単位体積重量

$\gamma_{0.5}$ : 剛性低下率が 0.5 となるときのひずみ, $h_{\max }$ : 最大減衰定数

制御できる ${ }^{12)}$ と考え, 許容応力度設計 ${ }^{13)}$ に従う現状の場所打ちコン クリート杭（長期軸力比 $\sigma 0 / \sigma B$ が 0.1 程度）に対して断面積が $2 / 3$ と なる拡底杭（長期軸力比 $\sigma 0 / \sigma \mathrm{B}$ が 0.15 程度）を設定する。

共同住宅は $\mathrm{X}$ 方向 1 スパン, $\mathrm{Y}$ 方向 6 スパンであり，2 階以上が 連層耐震壁で 1 階が独立柱となるピロティ構造である。基準階伏図 を図-1(1)に，立面図および解析モデルを図-1(2)に示す。

事務所はX 方向 6 スパン, $\mathrm{Y}$ 方向 3 スパンのほぼ均等スパンの ラーメン構造である。基準階伏図を図-2(1)に，立面図および解析 モデルを図-2(2)に示す。

部材および地盤等のモデル化は後に示すが，本解析モデルにおけ る固有値解析の結果を表 -2 に示す。連 成系の地震応答を大きく支配する 1 次 のモードに関して, 連成系の固有周期 $T \mathrm{cl}$ は, 基礎固定とした上部構造の固有 周期 $T \mathrm{u} 1$ に対して 2 倍程度となってお

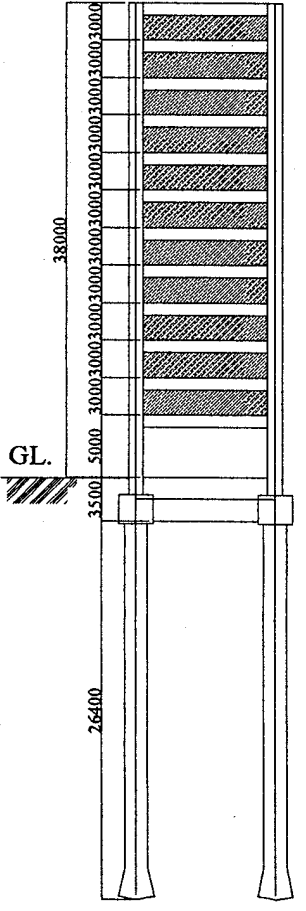

(xi) (x2) X1

(2) 立面図および解析モデル
(Y7)-

(Y6)-

(Y5)-

(Y4)-

(Y3)

(Y2)-

(Y1)

$\mathrm{Y}$ 方向

4

$\leftarrow$

×方向

（1）基準階伏図

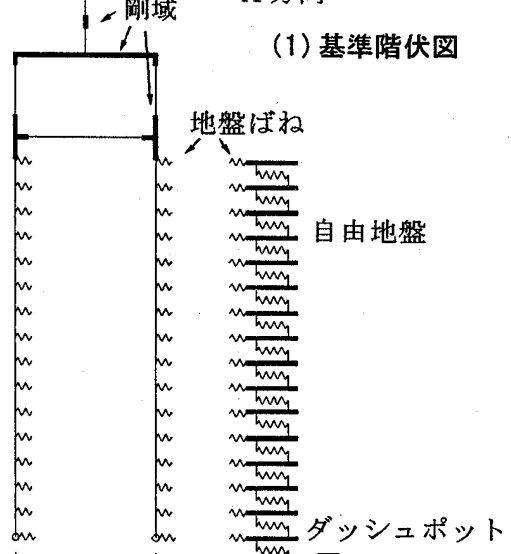

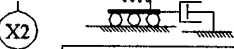

工学的基盤

图-1 12 階建て共同住宅 (ピロティ構造)

表 -2 固有値解析の結果

\begin{tabular}{|c|c|c|c|}
\hline 建物形式 & $\begin{array}{c}T \mathrm{u} 1 \\
(\mathrm{sec})\end{array}$ & $\begin{array}{c}T_{\mathrm{cl}} \\
(\mathrm{sec})\end{array}$ & $\begin{array}{c}\eta_{\mathrm{H}} \\
(\%)\end{array}$ \\
\hline 共同住宅(ピロティ構造) & 0.49 & 1.25 & 49 \\
\hline 事務所(ラーメン構造) & 0.78 & 1.24 & 45 \\
\hline
\end{tabular}

$T_{\mathrm{u} 1}$ : 基礎固定とした上部構造の 1 次固有周期, $T_{\mathrm{cl}}$ : 上部構造·杭 基礎・地盤の連成系における 1 次固有周期， $\eta_{\mathrm{H}}$ : 1 次モードにお けるスウェ一率 $=u \mathrm{~F} / u \mathrm{r}, u \mathrm{~F}$ : 基礎梁位置の水平変位, $u \mathrm{~T}$ : 建物頂 部の水平変位

*自由地盤の 1 次固有周期 $T_{\mathrm{g} 1}=0.70 \mathrm{sec}$

り，スウェー率 ${ }^{14)}$ (「建物頂部の変位」に対する「基礎梁位置の水平 変位」の比）は 49-45\% 程度である。

\section{2 解析方法}

解析では, 対象とする 1 構面を取り出し, 上部構造・杭基礎連成 で線材置換する。この平面骨組みと多質点系の自由地盤を地盤ばね で結ぶ方法により，建物と地盤の連成を表現する。
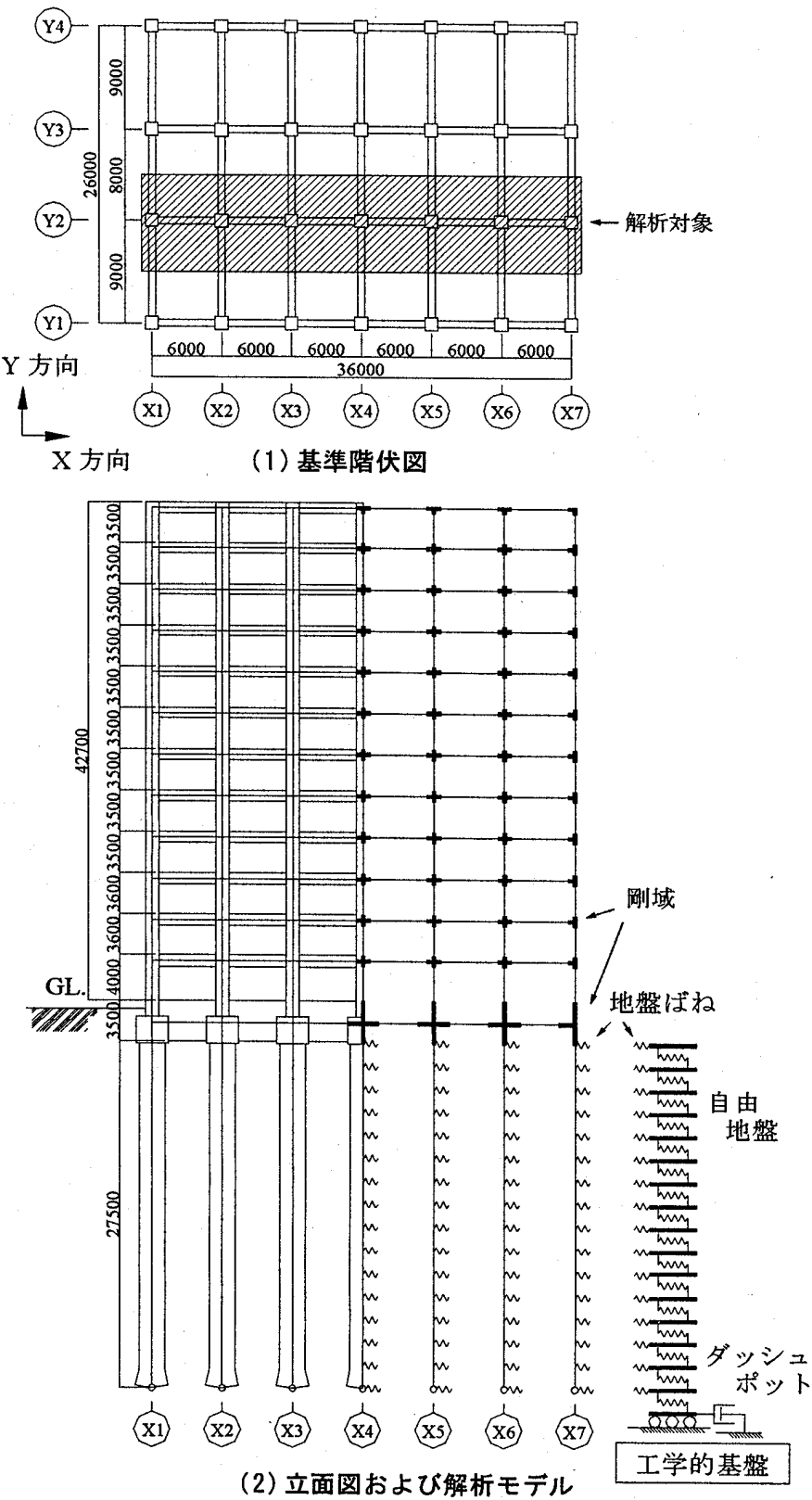

図-2 12 階建て事務所 (ラーメン構造) 
内部減衰は瞬間剛性比例型とし, 上部構造, 杭, 地盤ばね, お よび自由地盤の減衰定数を上部構造の弾性 1 次固有周期に対して 一律に 3\%とする。

\section{2.1 地震動}

工学的基盤における地震動は, 国土交通省告示 1461 号に示される 「極めて希に発生する地震動」の加速度応答スペクトルに対応させた 模擬地震動であり, 位相特性として神戸海洋気象台 NS と El Eentro 1940 NS の2つを用いる。図-3に時刻歴波形を, 図-4に加速度応答 スペクトルを示す。
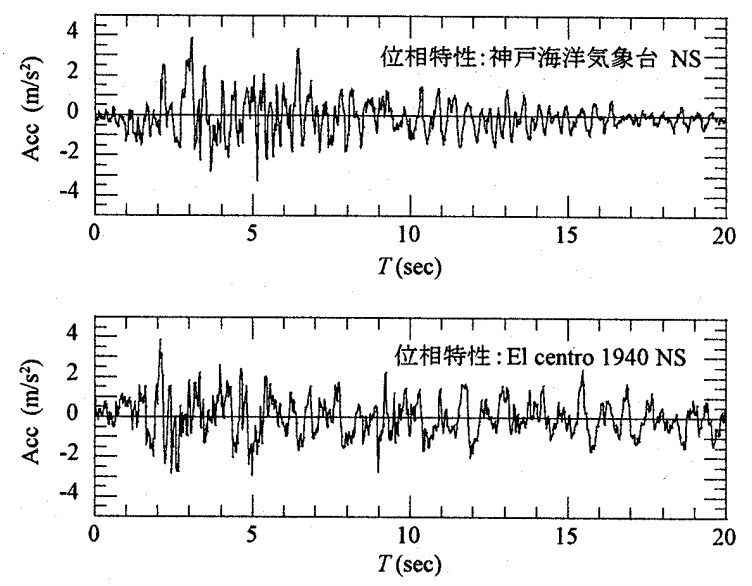

図-3 地震動の時刻歴波形

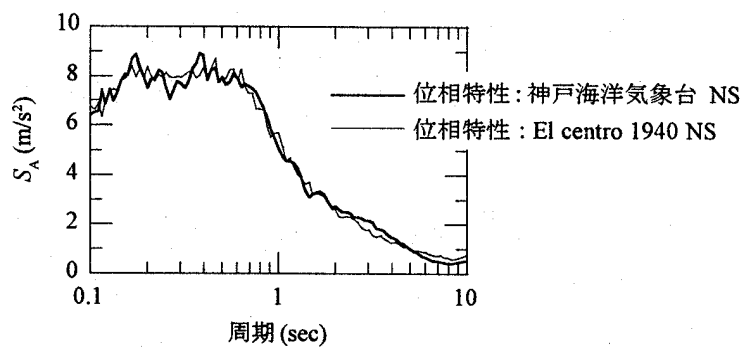

図 -4 地震動の加速度応答スペクトル

\section{2. 2 部材のモデル化}

柱, 梁, 壁, 杭は, それらの材中心軸に位置する線材とし, 柱・ 梁接合部および杭・基礎梁接合部は, 柱, 梁 (基礎梁), 杭のフェー ス位置まで剛域とする。また, いずれの部材も軸剛性およびせん断 剛性は弾性とする。

(1) 杭

杭は材軸方向に分割し，各要素の曲げ特性は中央の曲げモーメン ト $M$ と曲率 $\phi$ の関係で代表する。分割長さは杭頭を杭径の半分 $0.5 D$, その他を杭径 $D$ とする。杭の各節点は, 自由地盤の対応する染さ位 置と地盤ばねで結ぶ。周面摩擦ばねをつけていないので, 杭頭から 杭先端までほぼ等しい軸力が作用することとなる。なお, 水平加速 度に対しては，杭自重に加えて杭径の 3 倍（おおよそ杭の最小間隔 に相当）の径を持つ土柱の質量を付加質量として各節点に与えて いる。

杭の履歴則は，ディグレーディングトリリニアモデル(5)に従うこ ととする。 $M-\phi$ 骨格曲線は, 曲げひび割れ強度に達するまでの第 1 剛 性を $E I$ ( $E$ : コンクリートのヤング係数, $I$ : 杭の断面二次モーメント）
とし，曲げひび割れ強度 $M \mathrm{c}$ を(1) 式から求める。

$$
M_{\mathrm{c}}=0.56 \sqrt{\sigma \mathrm{B}} \cdot Z+\frac{N \cdot D}{8} \quad\left(\mathrm{~N} / \mathrm{mm}^{2}\right)
$$

$\sigma B:$ コンクリートの圧窂強度, $Z$ : 杭の断面係数, $N$ : 軸力, $D$ : 杭径 曲げ降伏強度には $\mathrm{e}$ 関数曲げ解析 ${ }^{16}$ により求めた最大耐力を用いる。

第 2 剛性，降伏強度以降の剛性，および除荷剛性は，せん断スパ ン比 2.5 (杭頭固定条件の Chang 式において $N$ 値 $=3$ を仮定して算出) のキャンティレバー実験の結果 ${ }^{4177}$ に，試験体解析を合わせるかたち で決定する。試験体諸元を表 -3 に示す。試験体解析における杭の 分割長さは $0.5 D$ である。

解析との対応により，曲げひび割れ発生後の第 2 剛性は第 1 剛性 の 0.3 倍とする（軸力の影響は考慮していない）。降伏強度以降の剛 性は第 1 剛性の 0.01 倍とする。除荷剛性 $K \mathrm{~d}$ は (2) 式による除荷剛性 低下係数 $\alpha^{\prime 15)}-0.45$ とする。実験值と計算值の比較を図 -5 に示す。

$$
K \mathrm{~d}=K_{1}\left|\frac{\phi_{\max }}{\phi c}\right|^{\alpha^{\prime}}
$$

$K_{1}$ : 第 1 㴊性 $(M c / \phi c), \phi \max$ : 最大経験曲率， $\phi c$ : 曲げひび割れ発生 曲率

表 -3 試験体一覧

\begin{tabular}{|c|c|c|c|c|c|c|}
\hline 試験体 & $\begin{array}{c}N \\
(\mathrm{kN})\end{array}$ & $\sigma_{\mathrm{n}} / \sigma \mathrm{B}$ & $\begin{array}{c}\sigma \mathrm{B} \\
\left(\mathrm{N} / \mathrm{mm}^{2}\right)\end{array}$ & $\begin{array}{c}P_{\mathrm{g}} \\
(\%)\end{array}$ & $\begin{array}{c}D \\
(\mathrm{~mm})\end{array}$ & $M / Q D$ \\
\hline $\mathrm{B} 350-25-2 \mathrm{H}-16$ & 370 & 0.16 & 24 & 2.0 & 350 & 2.5 \\
\hline $\mathrm{B} 350-25-2 \mathrm{H}-48$ & 1390 & 0.48 & 30 & & & \\
\hline
\end{tabular}

$N$ :軸力 $\sigma_{\mathrm{n}} / \sigma \mathrm{B}$ :軸力比 $\sigma \mathrm{B}:$ :ンクリート圧縮強度 $P \mathrm{~g}$ :全主筋比 $D:$ 杭径 $M / Q D$ :せん断スパン比

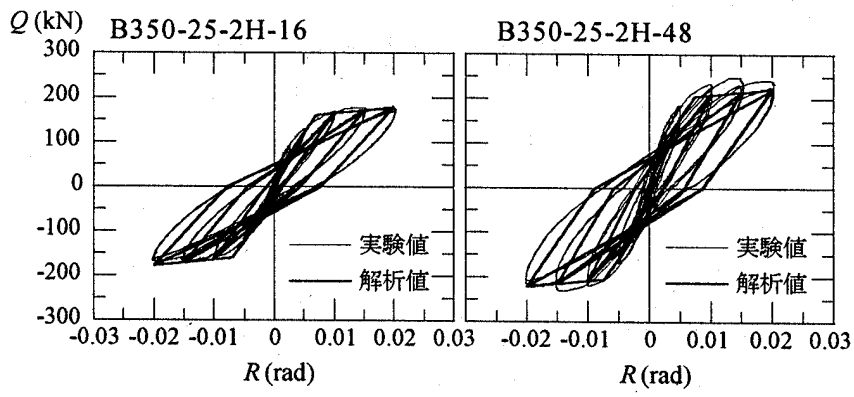

図 -5 実験値と解析値の比較(せん断カ一部材角関係)

連成解析の軸力変動に対しては, 曲げ解析から $M-N$ インターラク ションを設定し，最大点指向を図 6 に示すように，最大経験曲率と 各ステップごとに更新される骨格 曲線の交点を目指すルールとする。

(2) 梁，柱，壁

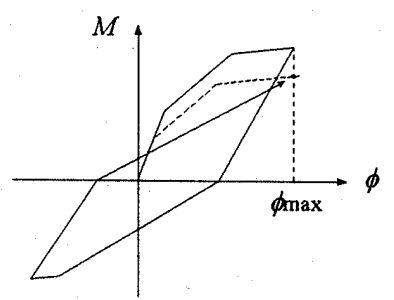

図 -6 杭の最大点指向

\section{1）共同住宅（ピロティ構造）}

1 階柱以外の基礎梁, 壁は弾性部材とする。各層の壁は曲げ変形 (曲率 $\phi)$ とせん断変形（せん断変形角 $\gamma$ ) を(3) 式で算定する 1 本の 線材に置換し，境界梁部分は剛体とする。

$$
\phi=\frac{M}{E \cdot l_{w}} \quad, \quad \gamma=\frac{Q}{G \cdot A w}
$$

$I \mathrm{w}$ : 付帯柱も含めた耐震壁の断面 2 次モーメント, $G$ : コンクリー トのせん断弾性係数, $A$ w: 耐震壁の断面積 
1 階柱は材端ばねモデルを用いており，材端モーメントと材端回 転角の関係は第 1 剛性 $K 1$ を を(4) 式から求める。

$$
K_{1}=\frac{6 E \cdot I}{l}
$$

$I:$ 断面 2 次モーメント, $l$ : 内法スパン長

1 階ピロティにおいては, 層せん断力と層間変形角の関係が重要で あるので, 柱の曲げひび割れ強度および曲げ降伏強度に対する軸力 変動の影響は考虑せず7，長期軸力作用下における曲げひび割れ強度 と曲げ降伏強度を採用する。

骨格曲線に関しては部材降伏時の剛性低下率を文献 18) から求め, 降伏後の剛性を第 1 剛性の 0.001 倍とするトリリニア型とする。履 歴則にはディグレーディングトリリニアモデル ${ }^{19)}$ を用いる。

2) 事務所（ラーメン構造）

梁部材は材端ばねモデルを用い，材端モーメントと材端回転角 の関係は第 1 凬性 $K 1$ を (4) 式で算定する。曲げひび割れモーメント は長方形断面として算定し, 降伏モーメントは上端（スラブ）が 引張側になる場合と下端が引張側になる場合の平均値とする。

骨格曲線に関しては部材降伏時の剛性低下率を文献 18) から求め, 降伏後の剛性を第 1 剛性の 0.001 倍とするトリリニア型とする。履 歷則にはディグレーディングトリリニアモデル19)を用いる。ただ し基礎梁は弾性とする。

柱部材においては, 最上階柱頭と最下階柱脚のみ共同住宅と同 様のモデルを用い，他は弾性とする。

\section{2. 3 地盤ばねおよび自由地盤のモデル化}

\section{（1）地盤ばね}

各深さにおける地盤ばねの骨格曲線は、極限地盤反力 $p^{i}$ max に漸 近する双曲線モデルとする ${ }^{20)}$ 。このとき地盤反力 $p$ と変位 $\delta$ の関係 は(5)式で与えられる。

$$
p=\frac{K^{i} \cdot \delta}{1+\frac{|\delta|}{\delta}}
$$

$K^{i} \mathrm{~h}$ : 初期剛性, $\delta$ : 基準変位 $\left(\delta=p^{i} \max / K^{i} \mathrm{~h}\right), p^{i}$ max: 極限地盤反力

初期剛性 $K^{i} \mathrm{~h}$ は水平地盤反力係数 $k^{i} \mathrm{~h}$ に杭径 $D$ 之節点に対応する杭 長 $l$ を乗じた值である。ここでは(6)式に示すように，一様線形地盤 を仮定した Chang 式に用いる水平地盤反力係数 ${ }^{21)}\left(\right.$ 杭頭変位 $\delta_{0}=$ $10 \mathrm{~mm}$ のときの值）を採用する。

$$
k \mathrm{~h}=80 E_{0} \cdot D^{-\frac{3}{4}} \quad\left(\mathrm{kN} / \mathrm{m}^{3}\right)
$$

$E_{\mathrm{o}}$ : 地盤の変形係数 $=700 \mathrm{~N}, N: N$ 值

一方, 各深さにおける $k^{\mathrm{i}} \mathrm{h}$ は，この值を 0.79 倍に低減するべきであ るという指摘がなされている22)。今回の場合は，これを初期剛性に 用いており，地盤ばね変位 $\delta=10 \mathrm{~mm}$ のときの割線剛性は (6) 式にお ける値の 0.87-0.94 倍となっている。

極限地盤反力 $p^{i}$ max は, 砂質土と粘性土に対して Broms の式 ${ }^{21)} よ$ り求める。

$$
p^{i}{ }_{\max }=3 \sigma_{0} \cdot K_{\mathrm{p}} \cdot D \cdot l, \quad p_{\text {max }}^{i}=9 \mathrm{cu} \cdot D \cdot l
$$

$\sigma_{0}: i$ 節点における鉛直応力, $K_{\mathrm{p}}$ : 受動土圧係数 $=(1+\sin \phi) /(1-\sin \phi)$, $\phi:$ 内部摩擦角 $=\sqrt{20 N}+15$ (度)， $c u$ : 非排水せん断強さ $=10 N(\mathrm{kN} /$ $\mathrm{m}^{2}$ )
履歴曲線には Masing 則 23) を適用する。地盤ばねの履歷 特性を図-7に示す。

\section{（2）自由地盤}

自由地盤は，せん断土柱 を質点化しており，入射基 盤は江戸川層上面とする。

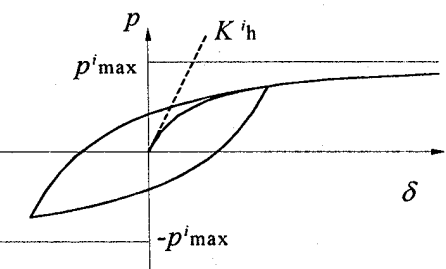

図 -7＼cjkstart地盤ばねの履歷特性
基盤面以深の半無限地盤の影響を表すために，基部には(8) 式に示

す減衰係数 $C$ のダッシュポットをつける ${ }^{24)}$ 。

$$
C=\rho \cdot V_{\mathrm{s}} \cdot A
$$

$\rho$ : 江戸川層の単位体積重量, $V_{\mathrm{s}}$ : 江戸川層のせん断波速度, $A:$ 土 柱断面積

土柱断面積は，各質点の重量が建物重量に対して十分大きくな るように決めている。土の応力 $\tau$-ひずみ $\gamma$ 関係は (9) 式に示す修正 Ramgerg-Osgood モデル ${ }^{23)}$ により骨格曲線を与え, Masing 則を用 いて履歴曲線を表した。

$$
\gamma=\frac{\tau}{G_{0}}\left(1+\alpha|\tau|^{\beta}\right)
$$

$G_{0}:$ せん断弾性係数, $\alpha, \beta$ : 正の定数 ここで, 定数 $\alpha, \beta$ は (10) 式によって求めるものとする。

$$
\beta=\frac{2 \pi \cdot h_{\max }}{2-\pi}, \quad \alpha=\left(\frac{2}{\gamma_{0.5} \cdot G_{0}}\right)^{\beta}
$$

$h_{\max }$ 最大減衰定数, $\gamma_{0.5}$ : 剛性低下率 $G / G_{0}$ が 0.5 になる時のひずみ なお， $h_{\max }, \gamma_{0.5}$ は土の資料を用いた動的変形試験結果から求めら れる值であり，文献11) より引用した值を表 -1 に示す。

\section{3. 杭基礎と上部構造の耐カ比}

上部構造の慣性力に対する静的プッシュオーバー解析を行ない， 設定する各杭において上部構造が保有耐力に達した時点における杭 頭降伏状沉を求める。解析概要を以下に示す。

反力として自由地盤側を固定とした地盤ばねを用いており，ばね の骨格曲線は動的解析と同様である。杭，上部構造の各部材モデル も動的解析と同様である。外力はX正方向に与えられ，分布形に関 して, ピロティ構造は矩形分布 ${ }^{25)}$ とし，ラーメン構造は $A \mathrm{i}$ 分布に基 づき算出する。基礎部分は 2 階スラブ位置と等しい水平震度を用い る。

建物を支持する杭に関して，ピロティ構造は，(1)杭が曲げ降伏し ない場合 (P-25), (2)引張側のみ曲げ降伏する場合 (P-15), (3)引張側 から圧縮側まで曲げ降伏する場合 (P-10)の3 ケースを設定する。

ラーメン構造は, (1)杭が曲げ降伏しない場合 (R-20), (2)引張側か ら圧縮側まで曲げ降伏する場合 (R-06)の 2 ケースを設定する。

杭諸元を表 -4 に示す。

解析の結果, ピロティ構造, ラーメン構造ともに, 杭頭降伏が 1 階 の層せん断力と層間変形角の関係に大きな影響を及ぼさなかった。 これは, 基礎梁が十分な剛性を持っているためである。1 階層せん断 力係数と層間変形角の関係, および杭頭降伏時の 1 階の層せん断力 係数を図 -8 に示す。

ここで杭頭が降伏する場合について，「上部構造の保有耐力時 1 階 
層せん断力」に対する「杭頭降伏時 1 階層せん断力」の比を「杭基 礎と上部構造の耐力比 $\lambda 」$ と定義する。杭頭降伏時 1 階層せん断力は, 各通りの平均値を用いる。P15 の場合は, 1 階柱の降伏強度を高めた 解析において Xp2 通り（変動軸力の圧縮側）まで降伏させて, 圧縮 側と引張側の平均値を求める。耐力比 $\lambda$ を表 -4 に示す。

表 -4 杭諸元および耐力比

\begin{tabular}{|c|c|c|c|c|c|c|c|}
\hline 上部建物 & 杭種別 & $\begin{array}{c}D \\
(\mathrm{~m}) \\
\end{array}$ & $\begin{array}{c}\sigma \mathrm{B} \\
\left(\mathrm{N} / \mathrm{mm}^{2}\right) \\
\end{array}$ & $\sigma 0 / \sigma_{\mathrm{B}}$ & $\begin{array}{l}P \mathrm{~g} \\
(\%) \\
\end{array}$ & $\begin{array}{c}\sigma_{\mathrm{y}} \\
\left(\mathrm{N} / \mathrm{mm}^{2}\right) \\
\end{array}$ & $\lambda$ \\
\hline \multirow{3}{*}{$\begin{array}{l}\text { 共同住宅 } \\
\text { (ピロティ) }\end{array}$} & P-25 & \multirow{3}{*}{1.6} & \multirow{3}{*}{24} & \multirow{3}{*}{0.154} & 2.5 & \multirow{3}{*}{400} & - \\
\hline & $\mathrm{P}-15$ & & & & 1.5 & & 0.95 \\
\hline & $\mathrm{P}-10$ & & & & 1.0 & & 0.83 \\
\hline \multirow{2}{*}{$\begin{array}{c}\text { 事務所 } \\
\text { (ラーメン }\end{array}$} & $\mathrm{R}-20$ & \multirow{2}{*}{1.8} & \multirow{2}{*}{24} & $0.146-$ & 2.0 & \multirow{2}{*}{400} & - \\
\hline & $\mathrm{R}-06$ & & & 0.174 & 0.6 & & 0.85 \\
\hline
\end{tabular}

$D$ :杭径, $\sigma \mathrm{B}$ : コンクリート圧縮強度, $\sigma 0 / \sigma_{\mathrm{B}}$ : 長期軸力比, $P_{\mathrm{g}}$ : 全主筋比, $\sigma_{\mathrm{y}}$ : 主筋降伏強度, $\lambda$ : 耐力比

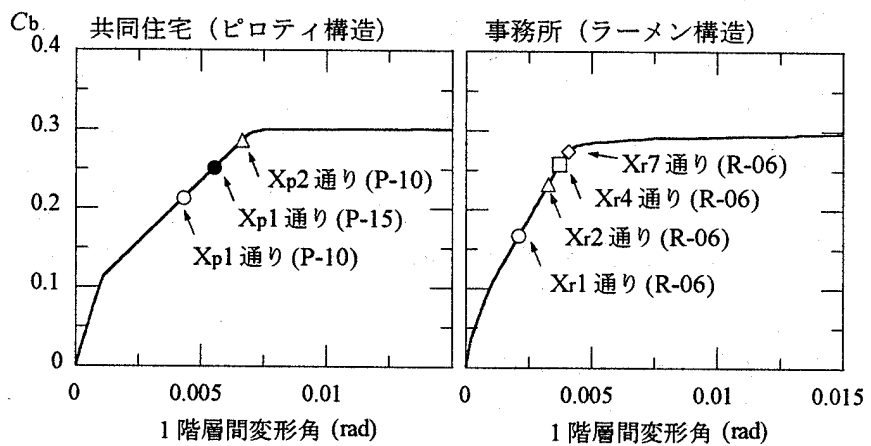

*プロットは杭頭降伏時。

* 耐力比 $\lambda$ に関わらず 1 階層せん断力係数と層間変形角の関係が等 しいため, ピロティ構造の場合にはP15 とP10の杭頭降伏時をあ わせて示す。

* $\mathrm{X}_{\mathrm{p} 1}$ 通り：共同住宅（ピロティ構造）の X1 通り。 $\mathrm{X}_{\mathrm{r}} 1$ 通り：事 務所（ラーメン構造）のX1 通り。他の通りもこれに準ずる。

\section{図-8 1 階の層せん断力係数と層間変形角の関係}

\section{4. 地震応答解析の結果と考察}

\section{1 自由地盤}

図 -9 に自由地盤の最大加速度分布と最大相対変位分布を示す。最 大加速度, 最大相対变位ともに神戸海洋気象台NSの位相特性を持つ 地震動の方が大きくなっているが, いずれの場合も表層地盤におけ る最大加速度の增幅は大きくなく, 最大相対変位分布においては最 もせん断波速度 $V \mathrm{~s}$ が小さい有楽町層下部粘土層（GL． - 7.5m）の非
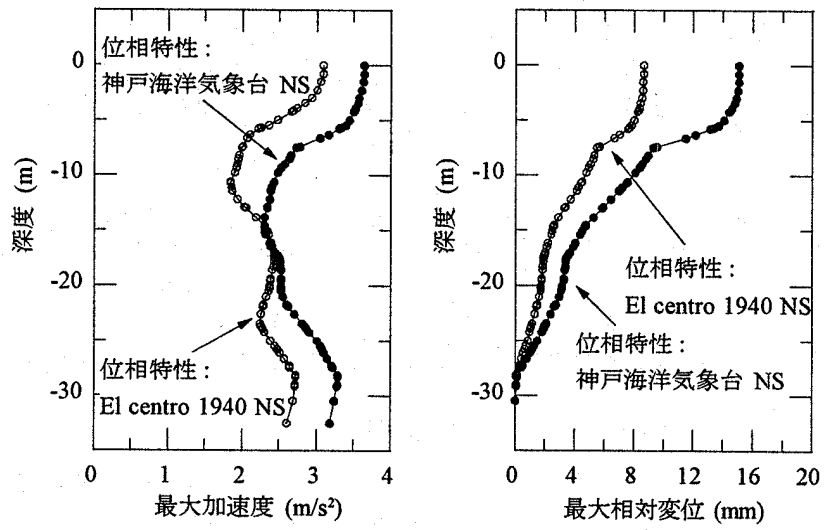

図 -9 自由地盤の最大加速度分布と最大相対変位分布
線形性が顕著となっている。また，基礎梁底面位置における最大応 答速度は, 神戸海洋気象台NS の位相特性を持つ地震動の場合が $0.83 \mathrm{~m} / \mathrm{s}$, El centro $1940 \mathrm{NS}$ の位相特性を持つ地震動の場合が $0.55 \mathrm{~m} /$ sであった。

\section{2 共同住宅(ピロティ構造)}

\section{2. 1 杭基礎の地震応答}

各杭の杭頭部（要素長さ $0.5 D$ ）における $M-\phi$ の関係を図 -10 に示 す。地震応答解析においては, 静的解析で杭頭降伏が生じなかった 場合（位相特性 神戸海洋気象台 : P-25における変動軸力の引張側 およびP-15 の圧縮側, 位相特性 El centro 1940 NS : P-15 の圧縮側) においても, 地盤の強制変位により降伏が生じて曲率が若干進んで いる $^{10)}$ 。塑性変形は耐力比 $\lambda$ が小さくなるに従い大きくなる傾向にあ る。

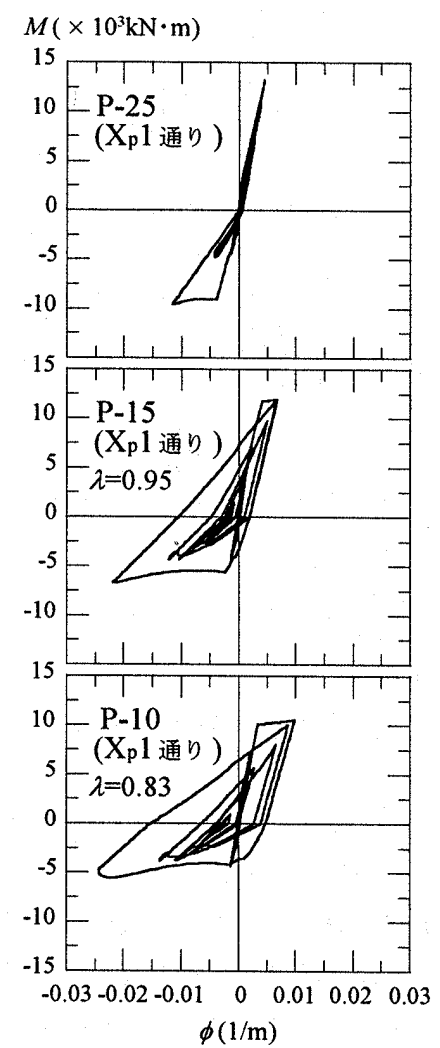

位相特性: 神戸海洋気象台 NS

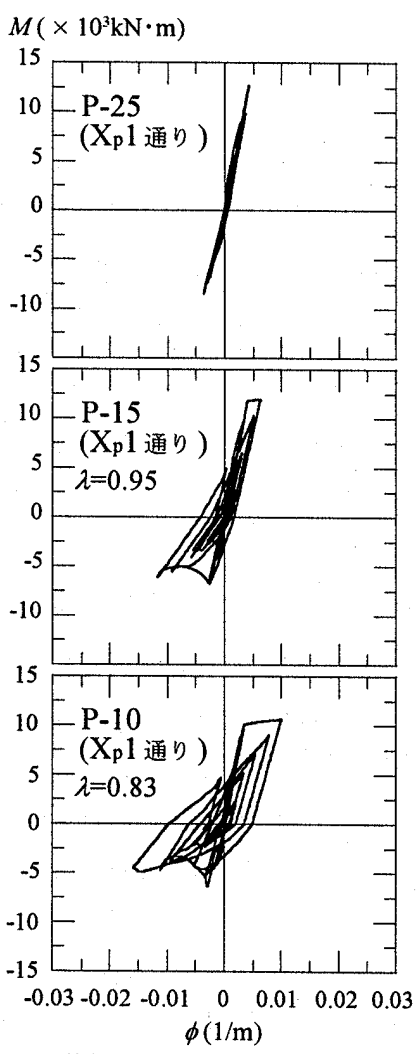

位相特性 : El centro $1940 \mathrm{NS}$

\section{図-10 杭頭におけるモーメントと曲率の関係（ピロティ構造）}

図-11 には杭の最大曲率分布の比較を示す。いずれの杭種におい ても杭頭において曲率が最大になっており，地中において顕著な塑 性変形は確認できない。図 -12 に静的解析の保有水平耐力時におけ る圧縮側の曲げモーメント分布と地震応答の最大曲げモーメント分 布 $\left(\mathrm{X}_{\mathrm{p}} 1\right.$ 通り)の比較を示すが，いずれの場合も，地中における最大 曲げモーメント地点が GL.-15m 付近でほぼ一致しており，本地震応 答解析においては上部構造の慣性力が杭の応答に支配的であったと いえる。

図-13 には基礎回転の時刻歷波形を示す。本解析においては杭の 軸剛性を弾性と仮定しており，基礎回転は軸力変動により生じる杭 の軸方向変形により生じることとなる。杭降伏の有無に関わらず, 軸力比 $\sigma \mathrm{h} / \sigma \mathrm{B}$ は, 圧縮側で +0.38 , 引張側で -0.07 の間にあったが (長 
期軸力比 $\sigma 0 / \sigma \mathrm{B}$ は 0.154)，これに伴い最大で $0.0012 \mathrm{rad}$ 程度の基礎回 転が生じている。

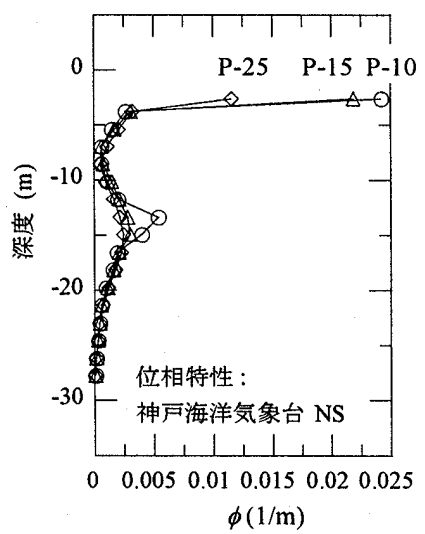

図-11 杭の最大曲率分布

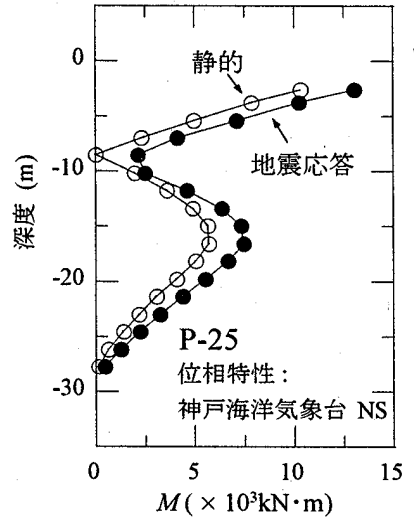

*静的プッシュオーバー解析の場合 は杭頭モーメントと地中最大モー メントの符号が逆となるが,ここ では絶対值で表示している。

図 -12 杭の最大曲げ モーメント分布

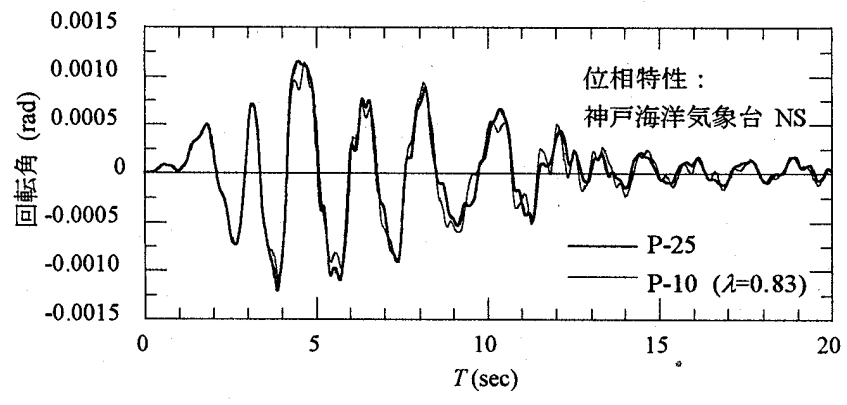

図-13 基礎回転の時刻歴波形（ピロティ構造）

\section{2.2 上部（ピロティ）構造の地震応答}

1 階の層せん断力係数の時刻歴波形と層間変形角の時刻歴波形を 図 -14 , 図-15 に示す。

P-25 と P-10 は杭頭の塑性変形に大きな違いがあるものの 1 階層せ ん断力係数の時刻歴波形はほぼ等しくなっている。

それに対して，層間変形角には杭頭塑性による顕著な違いが確認 できる。杭頭が降伏しないP-25に支持される場合に対して，杭頭が 降伏するP-15 と P-10 に支持される場合は，最大層間変形角が小さ く抑えられている。位相特性が神戸海洋気象台 NS の場合, El centro 1940 NS の場合のいずれにおいても，耐力比 $\lambda$ が最も小さく，杭頭の 塑性化が最も顕著な P-10 に支持される場合の最大層間変形角は, P25 に支持される場合のそれの半分以下となっている。

また, 図-13にも示したように，本解析における基礎回転は最大

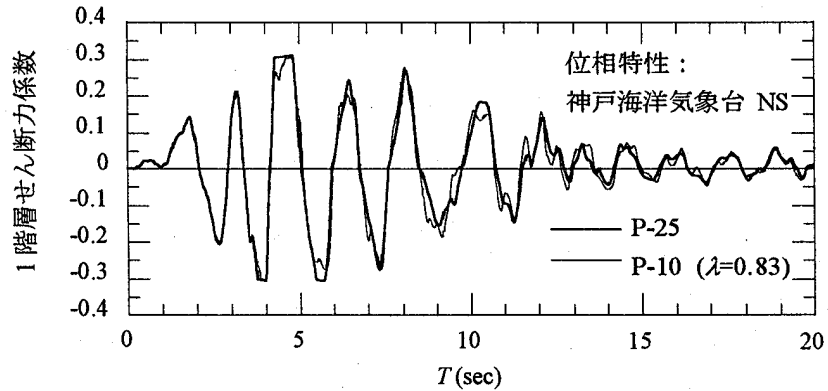

図-141 階層せん断力係数の時刻歴波形（ピロティ構造）
で $0.0012 \mathrm{rad}$ 程度であり，1 階層間変形角に大きな影響を与えていな い。
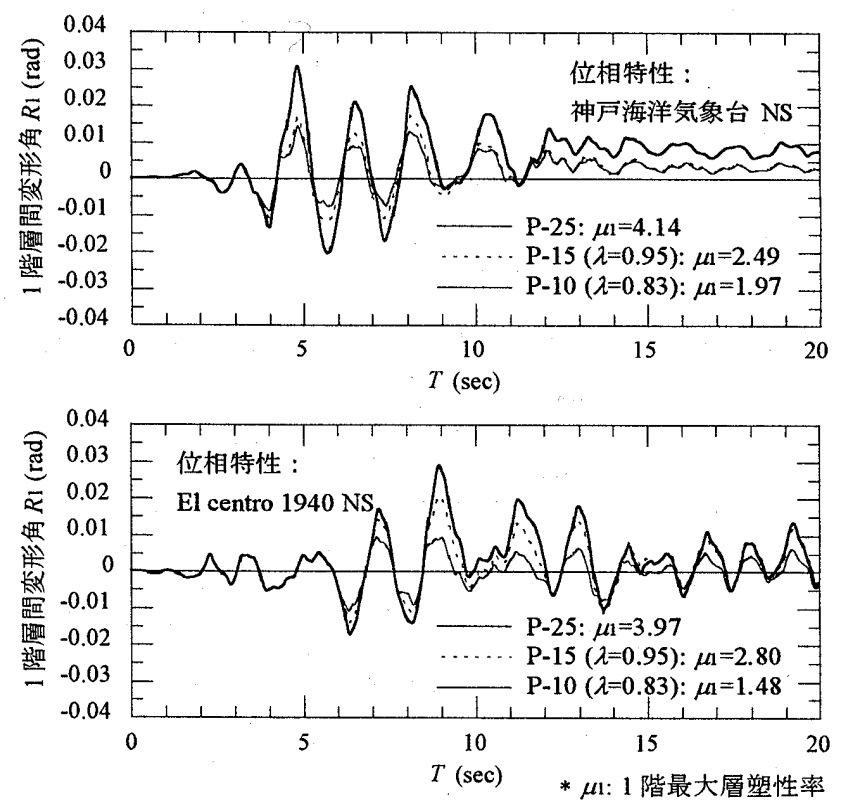

図-15 1 階層間変形角の時刻歴波形（ピロティ構造）

\section{3 事務所（ラーメン構造）}

\section{3.1 杭基礎の地震応答}

$\mathrm{R}-20$ と R-06 の杭頭部（要素長さ $0.5 D, \mathrm{Xr} 4$ 通り）における $M-\phi$ の 関係を図-16に示す。ピロティ構造の場合と同様, 耐力比 $\lambda$ が小さく なることにより，塑性変形が大きくなっている。紙面の都合上，図 は割愛するが, 杭の曲率分布およびモーメント分布における傾向も ピロティ構造の場合と同様で，上部構造の慣性力が支配的であった。

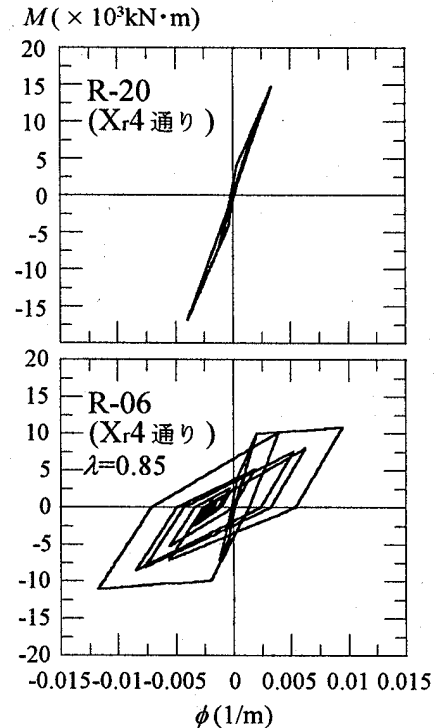

位相特性 : 神戸海洋気象台 NS

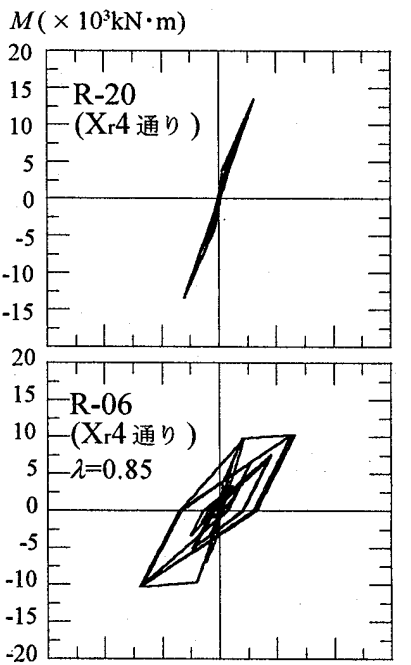

$-0.015-0.01-0.005 \quad 0 \quad 0.0050 .010 .015$ $\phi(1 / \mathrm{m})$

位相特性 : El centro $1940 \mathrm{NS}$
図-16 杭頭におけるモーメントと曲率の関係（ラーメン構造）

\section{3.2 上部（ラーメン）構造の地震応答}

紙面の都合上, 図は割愛するが，1階の層せん断力係数の時刻歷波 形はピロティ構造の場合と同様，杭頭降伏による影響は小さかった。 図 - 17 には, 中柱 $(\mathrm{X} \mathrm{r} 4$ 通り)に取り付く梁の各階における最大塑性 
率分布を示す。図より，R-06に支持される場合 $(\lambda=0.85)$ の最大塑性 率は，R-20に支持される場合よりも抑えられていることがわかる。 位相特性の違いにより分布形状は異なるものの，最も塑性化が進ん だ階について比較してみると，位相特性が神戸海洋気象台 NS の場合 は2.19が $1.44 に$ ，位相特性が El centro 1940 NS の場合は 2.13 が 1.69 に抑えられている。
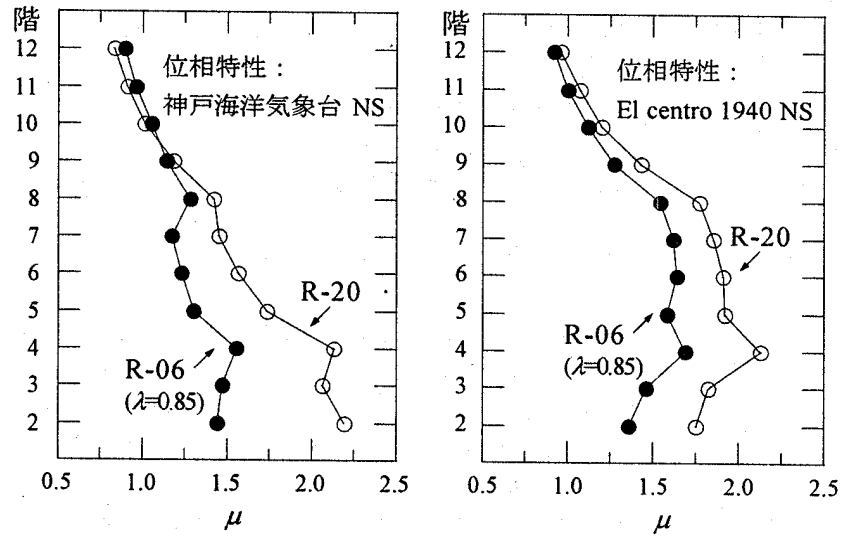

図-17 Xr 4 通りの柱に取り付く梁の最大塑性率分布

\section{4 建物が消費した累積エネルギー}

上部構造がピロティ構造の場合, ラーメン構造の場合を問わず, 杭頭が降伏することにより上部構造の塑性変形が抑制される結果と なった。

これに対して，建物が消費したエネルギーを考える。

図-18にはピロティ構造の累積消費エネルギーを, 図-19にはラー メン構造の累積消費エネルギーを示す。

上部構造に関して，ピロティ構造の場合は1階柱の消費した履歴 吸収エネルギーを, ラーメン構造の場合は基礎梁以外の全ての梁と 最上階の柱頭および最下階の柱脚の消費した履歴吸收エネルギーを 対象とする。基礎の場合は杭頭部における塑性化に差が出ているの で（図-11），杭頭の消費した履歴吸収エネルギーを対象とする。

いずれの場合も，杭頭が降伏することにより杭頭の累積消費エネ ルギーが大きくなっており，建物として消費するエネルギーのうち 上部構造と杭頭の比率が変化している。ピロティ構造の場合を見る と, その傾向は耐力比 $\lambda$ 小さいほうが顕著である。

また, 杭頭が降伏する場合, 建物として消費するエネルギーその ものも低減している。図-20には杭頭位置における地盤ばねの履歷 を示すが，杭頭が降伏することにより反力が大きくなり，それに伴 い変位（杭頭変位）も大きくなっている。これは, 杭頭降伏後にお いて杭頭の曲げ謫性が大きく低下したためである（第 1 剛性の 0.01 倍)。建物・地盤系の 1 次モードにおけるスウェイ率 $\eta \mathrm{H}$ が $50 \%$ 程度 （表 -2）であることを踏まえると地盤ばねの影響も小さくなく，杭頭 降伏により增大した地盤ばねの履歴吸収エネルギーの影響により， 建物に対する入力エネルギーが低減された ${ }^{26)}$ と考えることができる。

これら 2 つ要因は, 上部構造が消費するエネルギーの絶対量を 減少させ, 結果的に上部構造の塑性変形の抑制につながっている。

図-18および図-19には, 各場合における杭頭ヒンジ領域の最大回

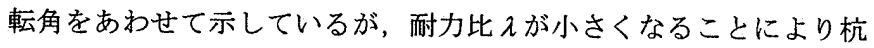
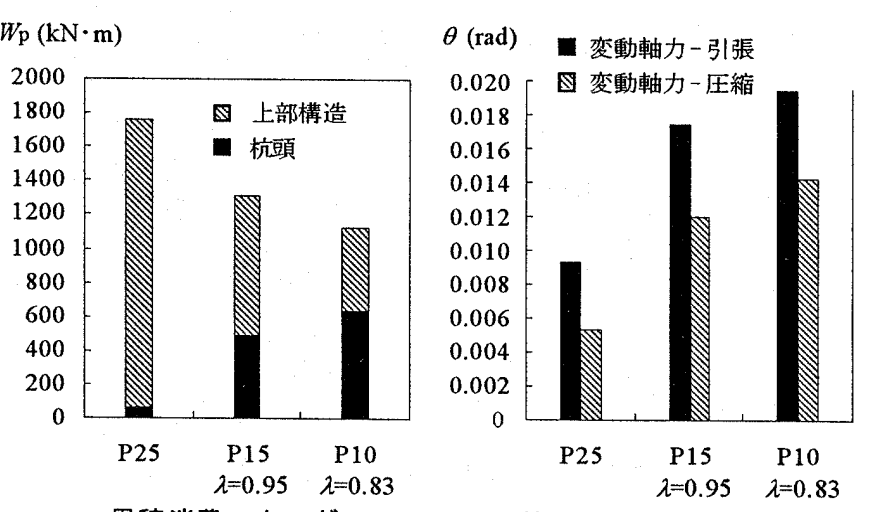

累積消費エネルギー

杭頭ヒンジ領域の最大回転角 位相特性: 神戸海洋気象台 NS

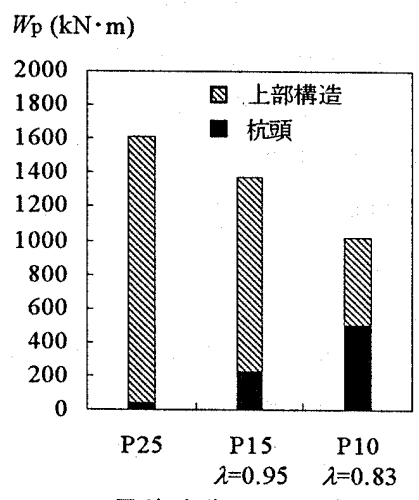

累積消費エネルギー

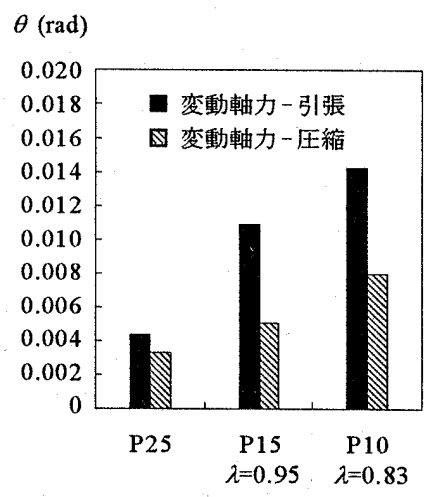

杭頭ヒンジ領域の最大回転角 位相特性 : El centro $1940 \mathrm{NS}$
図-18 ピロティ構造の累積消費エネルギーと杭頭回転角

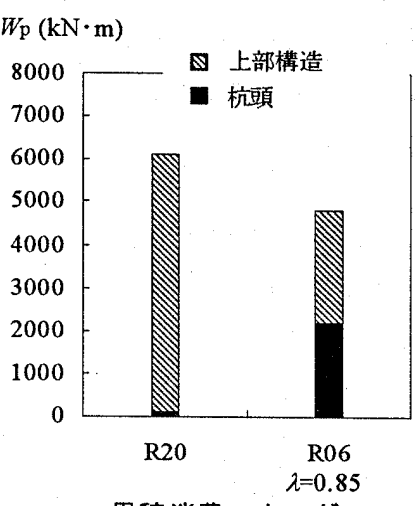

累積消費エネルギー
- 側柱下杭 変動軸力-引張

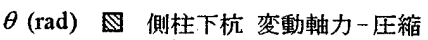
0.016 口 中柱下杭 $(\mathrm{Xr} 4)$

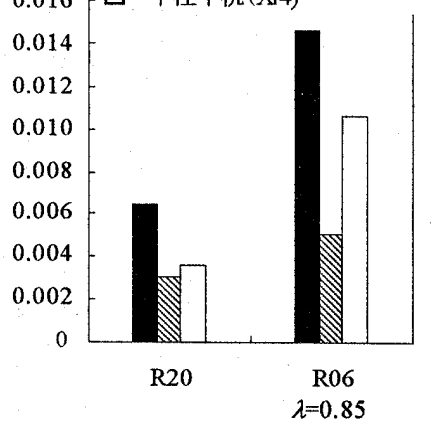

杭頭ヒンジ領域の最大回転角

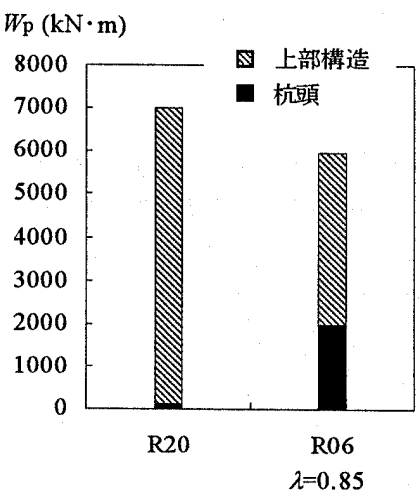
累積消費エネルギー

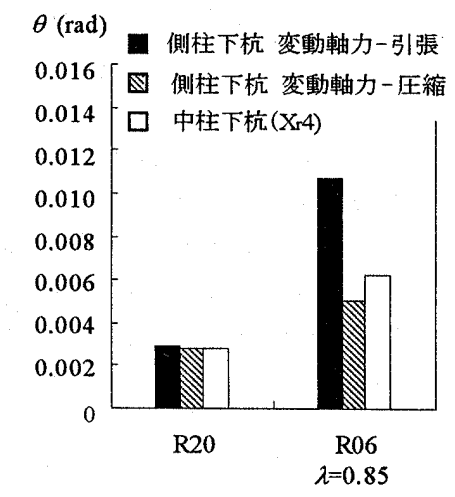

杭頭ヒンジ領域の最大回転角 柆相特性 : El centro $1940 \mathrm{NS}$

図-19 ラーメン構造の累積消費エネルギーと杭頭回転角 


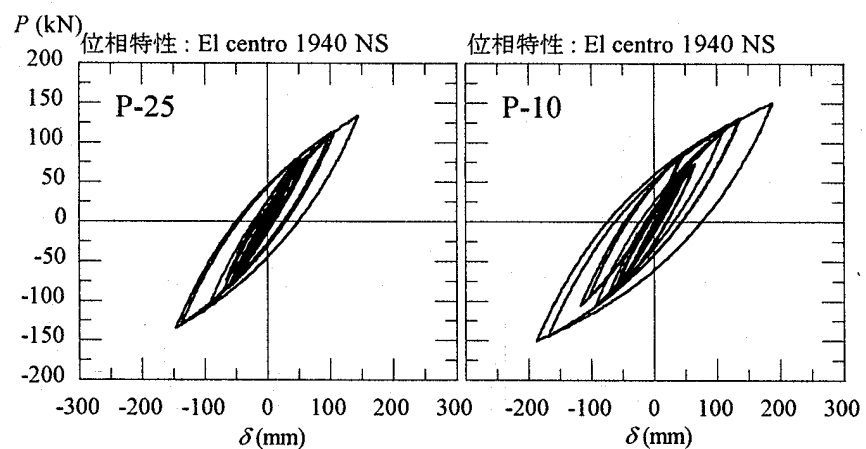

図 -20 地盤ばねの履歴（杭頭位置の反カー变位関係）

頭ヒンジ領域 $(0.5 D)$ に要求される回転角は大きくなることがわかる。 杭頭は回転角として変形能力が要求されるため, 実験における七 ンジ領域の広がりと対応させて，これを保証するようなせん断補強 と横拘束補強を施しておく必要がある。このような考え方は, 鉄筋 コンクリート柱においてはすでに確立されておりり ${ }^{576)}$, 杭の変形性能 に期待する場合においては,こうした観点からの設計が必要である。

\section{5. 結論}

本研究においては，杭の塑性化が上部構造の塑性性状に及ぼす影 響を考察する目的で上部構造・杭基礎・地盤連成の地震応答解析を 行った。敷地を軟弱地盤の台場とし，上部構造として 12 階建てのピ ロティ構造とラーメン構造を設定した。地震動としては神戸海洋気 象台 NS と El Centro 1940 NS の位相特性を有する 2 つの告示波を用 いた。

以上の条件のもとで得た知見をまとめると以下のようになる。

(1) 上部構造が保有耐力に達する前に杭頭の曲げ降伏を認めること で, 設計時に上部構造のクライテリアを決める要因となるピロティ 構造の 1 階層間変形角 (層塑性率), およびラーメン構造の梁塑性率 を抑制することができる。

(2) (1) で述べた現象は, 上部構造と杭基礎の消費した履歴吸収エネ ルギーのバランス，および杭周辺の地艋が消費した履歴吸収エネル ギーを考えることで，その傾向を説明できる。

(3) 杭基礎の上部構造に対する耐力比 $\lambda$ が小さいほど，すなわち杭頭 の降伏が上部構造の保有水平耐力に対して早く発生するほど, 上部 構造の損傷を减少させることができるが，それに対応して杭頭に要 求される塑性変形能力が大きくなる。このような場合には変形能力 を保証するせん断補強と横拘束が必要となる。

\section{謝辞}

本研究に際して, 佐藤工業中央技術研究所 岩藤正彦所長, 同 長縄裕行建築研 究部門長に多大なご協力を頂きました。大阪大学大学院工学研究科 中塚佶助教授, 東京工業大学建築物理研究センター 篠原保二助教授, 同 香取慶一助手, 佐藤工 業中央技術研究所 柳瀬高仁主任研究員には貴重なご意見を頂きました。

また, 本研究は東京工業大学建築物理研究センタ一全国共同研究の一環として行 われたものです。関係者各位に対して，付して感謝の意を表します。

\section{参考文献}

1) 西山峰広, 六車熙, 渡辺史夫: 高一様伸び鎘棒と横拘束併用による高強度 $\mathrm{PC}<$ いの曲げ勒性改善, コンクリート工学年次講演会論文集, Vol.9, No.2, pp.477-482, 1987

2) 黒正清治, 堀井昌博, 和田章, 林静雄, 小林克巳, 渡辺厚, 光木史朗, 上田邦成: 高強度PC杭の中空部にコンクリートを中詰した効果に関する研究, 日本建築学会 構造系論文報告集，第 390 号，pp.134-141，1988，8

3)長江拓也, 岸田慎司, 香取慶一, 林静雄: PRC杭の耐震性能に及ぼ寸軸方向異形 鉄筋と横補強筋の影響, 日本建築学会構造系論文集, 第538号, pp.123-129, 2000, 12

4)長江拓也, 香取慶一, 林静雄: 軸部を細くした場所打ちコンクリート杭の耐震性 能，日本建築学会論文報告集，第 542 号，pp.139-146，2001.4 5) 鉄筋コンクリート造建物の終局強度型耐震設計指針·同解説, 日本建築学会, 1990

6) 鉄筋コンクリート造建物の靭性保証型耐震設計指針·同解説，日本建築学会， 1999

7)小室努, 川端一三, 小谷俊介 : 2 階以上に連層耐力壁を有するピロティ建物の地 震応答性状, コンクリート工学年次論文報告集, Vol.18, No.2, pp.755-760, 1996 8)酒向裕司, 宮本裕司:変動軸力を考慮した杭基礎の地震态答に関する解析的検討, 日本建築学会論文報告集，第 523 号, pp.79-86, 1999.9

9)長谷川正幸, 護雅史, 淵本正樹, 浅香美治 : 1995 年兵庫県南部地震における RC 杭支持建物の被災シュミレーションと杭基礎の耐震性能, 日本建築学会論文報告集, 第 543 号, pp.87-95,2001.5

10)宮本裕司，酒向裕司，岡安隆史: 杭支持建物の耐震性能評価に関する研究，日 本建築学会論文報告集, 第 547 号, pp.59-65, 2001.9

11)建築物の構造安全性に関する調查・検討一報告書, 構造解析部会·臨海部構造 安全委員会·日本建築防災協会, 1991.3

12)本庄正樹，長江拓也，柳瀨高仁，林静雄: 寸法が場所打ちコンクリート杭のせ ん断性状に及ぼす影響, コンクリート工学年次墖文報告集, Vol.23, No.3, pp.979984,2001

13)地震力に対する建築物の基礎の設計指針，日本建築センター, 1984

14)栗本修, 福和伸夫, 相互作用を考丕した上部構造への地震荷重, 第 5 回構造物 と地盤の動的相互作用シンポジュウム, pp.97-106, 1998.5

15)江戸宏彰, 武田寿一, 表祐太郎:3層 1 スパン鉄筋コンクリート骨組の動的破壊 実験 (その2. 実験結果の検討)，日本建築学会関東支部第44回研究報告集, pp.4548,1973

16)梅村魁: 鉄筋コンクリート梁の塑性変形および終局耐力, 日本建築学会論文報 告集 42 号, pp.59-70, 1951.2

17) 金東範，本庄正樹，長江拓也，柳瀬高仁，香取慶一，林静雄 : 軸部を細くした 場所打ちコンクリート杭の耐震性能 (高軸力作用下における場合), 日本建築学会大 会学術講演梗概集, B-1, pp.385-386, 2001

18）菅野俊介: 鉄筋コンクリート部材の復元力特性に関寸る研究，コンクリート ジャーナル, Vol.11, No.2, 1973

19)T.Takeda, M.A.Sozen, N.N.Nielsen: Reinforced Concrete Response to Simulated Earthquakes, Journal of the Structure Division, ASCE, ST12, pp.2557-2573, 1970

20)宮本裕司, 酒向裕司, 喜多村英司, 三浦賢治 : 非線形, 液状化地盤における杭 基礎の地震応答性状に関する研究, 日本建築学会論文報告集, 第471号, pp.41-50, 1995.5

21)建築基礎構造設計指針，日本建築学会，1988

22) 斎藤安生, 堀井昌博, 石井正人, 王学鋒: 地盤の塑性性状を考慮した杭の水平 地盤反力の定式化，日本建築学会大会学術講演梗概集， B-1，pp.699-700，1996.9 23) 入門·建物と地盤との動的相互作用, 日本建築学会, 1996

24)Joyner W.B.: A method for calculating nonliner response in two dimensions, Bulletin of the Seismological Society of America, Vol.65, No.5, pp.1337-1357, 1975

25)顧建華, 倉本洋, 松本和行, 福田俊文 : 鉄筋コンクリート造ピロティ建築物の 地震応答性状, コンクリート工学年次論文報告集, Vol.22, No.3, pp.25-30, 2000 26) 護雅史, 長谷川正幸:杭頭接合条件の異なる杭基礎建物の地震時挙動に関する 解析的研究-その1 RC杭の場合, 日本建筑学会大会学術講演梗概集, B-2, pp.921$922,2001.9$ 